\title{
In-work benefits for married couples: an ex-ante evaluation of EITC and WTC policies in Italy
}

\author{
Giuseppe De Luca ${ }^{1 *}$, Claudio Rossetti ${ }^{2}$ and Daniela Vuri ${ }^{3}$
}

\author{
${ }^{*}$ Correspondence: \\ giuseppe.deluca@unipa.it \\ 1 SEAS Department, University of \\ Palermo, Palermo, Italy \\ Full list of author information is \\ available at the end of the article
}

\begin{abstract}
This paper investigates labor supply and redistributive effects of in-work benefits for Italian married couples using a tax-benefit microsimulation model and a multi-sectoral discrete choice model of labor supply. We consider in-work benefits based on the Earned Income Tax Credit (EITC) and the Working Tax Credit (WTC) existing in the US and the UK, respectively. The standard design of these income support mechanisms is however augmented with a premium for two-earner households to avoid potential disincentive effects on secondary earners. Revenue neutral policy simulations show that our reforms may greatly improve the current Italian tax-benefit system in terms of both incentive and redistributive effects. Furthermore, neglecting sector-specific attributes of the various job opportunities may lead to overstated estimates of the policy effects.
\end{abstract}

JEL classification: $138 ; \mathrm{H} 31 ; \mathrm{H} 53$

Keywords: In-work benefits; Sectoral labor supply; Poverty; Microsimulation; Married couples

\section{Introduction}

In-work benefits are usually promoted as income support mechanisms that encourage employment in the low-skilled population while maintaining high levels of social protection. This twofold objective is achieved by providing means-tested transfers to low-income households with eligibility conditional on some employment requirement. Pioneering in-work benefit schemes are the Earned Income Tax Credit (EITC) in the US and the Working Tax Credit (WTC) in the UK, but similar policies have been recently implemented in a number of OECD countries.

Despite the general consensus on effectiveness of these welfare instruments for lone parents, the design of in-work benefits for married couples is still muddied by important concerns. Economic theory and previous empirical evidence suggest that family-based schemes, where the benefit is means-tested against household income, generally promote employment among primary household earners (Bargain and Orsini 2006; Blundell 2000; Blundell and Hoynes 2004; Eissa and Hoynes 2004; Eissa and Liebman 1996). Such schemes are likely to create, however, negative labor supply effects on secondary earners as their earnings may move households in regions of the budget set with high marginal tax

(c)2014 De Luca et al.; licensee Springer. This is an Open Access article distributed under the terms of the Creative Commons Attribution License (http://creativecommons.org/licenses/by/2.0), which permits unrestricted use, distribution, and reproduction in any medium, provided the original work is properly credited. 
rates (Eissa and Hoynes 2004). To contrast these unintended disincentive effects, some countries have experienced individual-based schemes where the benefit is means-tested against individual income (Immervoll and Pearson 2009). In this case, however, the major concern is a less efficient targeting of redistributive effects since transfers may also be provided to low-income workers in well-off households. Whether labor supply incentives and redistributive effects can be reconciled into a single welfare instrument is still an open issue.

This paper contributes to the literature on in-work benefits by proposing an innovative design of EITC and WTC schemes for married couples aimed to overcome potential disincentive effects on secondary earners. Our strategy consists of introducing a new benefit premium for two-earner households within otherwise standard familybased schemes that preserve an efficient targeting of redistributive effects towards poor working households. Effectiveness of the resulting in-work benefit schemes is assessed by means of policy simulations on the 2008 Italian welfare system using a national tax-benefit calculator and a structural model of labor supply. Unlike most of the previous studies using a similar policy evaluation approach, our structural model of labor supply draws upon the multi-sectoral discrete choice framework by Dagsvik and Strøm (2006) that jointly accounts for nonlinear and nonconvex budget sets, hourly wage differentials among jobs of different sectors, prediction errors in the hourly wages, observed and unobserved heterogeneity, and sector-specific quantity constraints. The original setup of the multi-sectoral model for a single decision maker is also extended, within a unitary framework, to the case of two decision makers to capture labor supply responses of both spouses. Further, we assess the implications of using alternative model specifications by comparing our multi-sectoral model with a simpler benchmark that ignores sector-specific attributes of the various job opportunities.

Differently from earlier ex-ante evaluations of in-work benefits for Italy (Colonna and Marcassa 2011; Figari 2011), our policy simulations focus on EITC and WTC in-work benefits for Italian married couples with a special emphasis on the new benefit premium for two-earner households. Policy reforms are simulated under budget neutrality by considering the abolition of Italian family allowances (FA). We find that in-work benefits with a suitable set of incentives for secondary earners may have strong positive effects on labor supply of wives and equity. The EITC is more effective than the WTC in boosting employment of wives, while the WTC is more effective than the EITC in fighting poverty. Most labor supply responses take place in the private sector where there is a greater availability of job opportunities and lower hourly wages with respect to the public sector. Moreover, neglecting sector-specific attributes of the various job opportunities may lead to overstated estimates of the policy effects.

The remainder of the paper is organised as follows. Section 2 provides a brief review of the EITC in the US and the WTC in the UK. Section 3 describes the Italian FA program and formalizes the EITC and WTC schemes simulated in our study. Section 4 describes the key ingredients of our evaluation tool including the tax-benefit calculator and the structural model of labor supply. Estimates of the labor supply model and wage elasticities are presented in Section 5, while policy simulations are presented in Section 6. Finally, Section 7 concludes. 


\section{In-work benefits in the US and the UK}

In-work benefits in the US and the UK have been discussed and compared in several studies, including Dickert et al. (1995), Eissa and Liebman (1996), Liebman (1998), Blundell (2000), Brewer (2000), Blundell et al. (2000), Meyer and Rosenbaum (2001), Neumark and Wascher (2001), Blundell et al. (2002), Blundell and Hoynes (2004), Eissa and Hoynes (2004), Brewer et al. (2006), Francesconi and van der Klaauw (2007), Leigh (2007), Gregg et al. (2009), Brewer et al. (2010), and Blundell and Shephard (2012), among others. In this section, we briefly review the design of these income support mechanisms to emphasize their disincentives on secondary earners.

\subsection{Design of the EITC and WTC programs}

A common feature of the EITC in the US and the WTC in the UK is that low-income households are entitled to a refundable tax credit (or benefit) provided that at least one adult member works and other eligibility criteria are satisfied.

To be eligible for the EITC, the taxpayer needs to meet two conditions: (i) positive earned income from employment or self-employment, and (ii) earned income, adjusted gross income and investment income below certain thresholds. Conditional on eligibility, the credit entitlement depends on family earned income according to separate schedules by filing status and number of eligible children. Each schedule includes a phase-in region where the credit is initially increased at a certain subsidy rate, a flat region where the credit is kept constant at the maximum amount, and a phase-out region where the credit is tapered away to zero. Subsidy rate, maximum credit amount, and taper rate vary with the number of eligible children leading to a more generous welfare program in favor of large households ${ }^{1}$.

To be eligible for the WTC, the claimant needs to work a minimum number of hours per week and fulfil other conditions related to either age, disability, responsibility for children or previous periods of unemployment benefits. The credit entitlement is equal to its maximum amount if gross annual income (jointly assessed in the case of couples) does not exceed a fixed disregard and is reduced at a certain taper rate above it. Compared to the EITC, an important difference is the lack of a phase-in region. Moreover, if the claimant works 30 hours or more per week, the maximum credit entitlement is shifted upward by the 30 hour element of the WTC schedule ${ }^{2}$.

\subsection{Disincentives on secondary earners}

The key insight from both economic theory and earlier empirical evaluations is that family-based in-work benefits like EITC and WTC are effective for some population groups like lone-parents and primary earners of married couples, but they lead to perverse effects on secondary earners of married couples whose labor supply decisions are known to be sensitive to financial incentives from the tax-benefit system. Despite its importance, this issue has received little attention compared with other problems such as the role of childcare, the problem of benefit take-up and stigma effects, and the evaluation of possible spillover effects with other parts of tax-benefit system. The use of familybased in-work benefits with extra credits for secondary earners has been recommended by Brewer et al. (2010) based on implications from the optimal taxation theory. To our knowledge, however, formalized policy designs and simulation results for the impact of such reforms are still lacking. 
Notice that in the UK and the US, the focus on lone parents may be partly justified by the large share of two-earner households with children. In Italy, however, this population group amounts to $45 \%$ due to the low labor market participation of married women. Thus, potential disincentives on secondary earners must be considered a more serious concern than in the US and the UK.

\section{Policy reforms}

Our policy reform consists of replacing the Italian FA program with a new system of in-work benefits, the size of which is adjusted to achieve budget neutrality. To avoid potential disincentives on married women, we propose an innovative design of the EITC and WTC which includes a suitable scheme of financial incentives for secondary earners of low-income households. A description of the FA program to be abolished is given in Section 3.1, while the EITC and WTC reforms are formalized in Sections 3.2 and 3.3 respectively.

\subsection{The Italian FA program}

The FA program provides family-based benefits that are exempt from taxation and means-tested against the number of eligible household members, household composition and gross household income. Its schedule distinguishes among 15 household groups, but our attention shall be focused on four groups only consisting of married couples with no disabled member and (i) no children, (ii) one child, (iii) two children, and (iv) three children, respectively. Eligibility is restricted to employees, temporary workers, unemployed covered by unemployment benefits, and former-employee pensioners. Self-employed are not eligible since at least $70 \%$ of gross household income is required to be from wages, salaries, and former-employee pensions. As shown in Figure 1, FA are strictly increasing with household size and non-increasing with gross household income. With the exception of childless couples, each household group faces an initial flat region of maximum

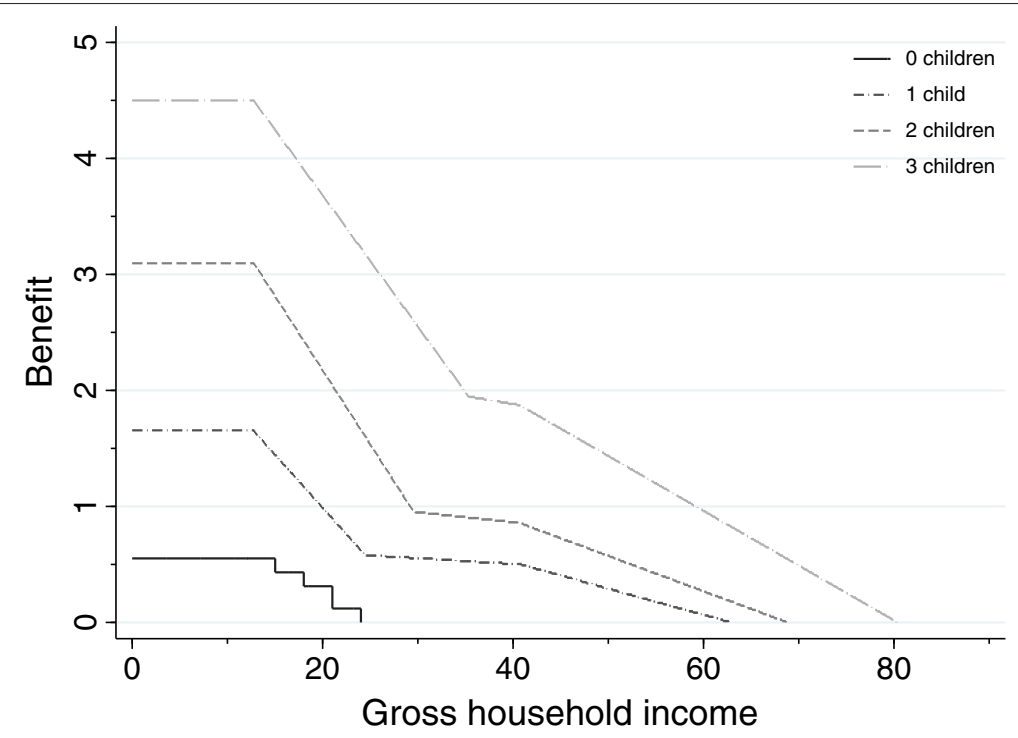

Figure $\mathbf{1}$ The $\mathbf{2 0 0 8}$ Italian family allowances by household type. Notes: Benefit amounts and gross household income are expressed in 1000 Euros. 
benefits and three subsequent phase-out regions. Although it is usually considered a welfare program to alleviate poverty, FA expire at rather generous income cut-off points (about 90th percentile of the gross income distribution for households with children). As discussed below, our in-work benefit reforms impose lower income cut-off points to collect resources from the right-hand-side of the household income distribution and then use these resources to finance a set of additional incentives for two-earner households with low income.

\subsection{The EITC reform}

Our EITC reform grants a benefit exemption from taxation which is means-tested against gross household income and household size. Eligibility is restricted to households with positive earnings, and policy coefficients are determined to ensure tax revenue neutrality for each household group after accounting for the abolition of FA. In this way, we anchor the budget of each household group to the amount available in the FA program. The schedule for one-earner households has the standard form

$$
\begin{aligned}
E_{c}=E_{c}^{*} & -\max \left\{0, \min \left\{E_{c}^{*}, t_{1 c}\left(G_{1 c}-G\right)\right\}\right\} \\
& -\max \left\{0, \min \left\{E_{c}^{*}, t_{2 c}\left(G-G_{2 c}\right)\right\}\right\}, \quad c=1,2,3,4,
\end{aligned}
$$

where $E_{c}^{*}$ is the maximum benefit of the flat region, $t_{1 c}=E_{c}^{*} / G_{1 c}$ is the subsidy rate of the phase-in region, $t_{2 c}=E_{c}^{*} /\left(G_{3 c}-G_{2 c}\right)$ is the taper rate of the phase-out region, $G_{t c}$, $t=1,2,3$, are the income cut-off points, and $G$ is gross household income. The schedule for two-earner households presents two differences. First, there is a higher maximum benefit $\bar{E}_{c}^{*}=\left(1+p_{c}\right) E_{c}^{*}$, where $p_{c} \geq 0$ is the benefit premium for two-earner households. Second, there are larger phase-in and phase-out regions to avoid that the benefit expires as secondary earners enter the labor market.

Imposing that length of the flat region, subsidy rate and taper rate do not change, the income cut-off points of the schedule for two-earner households are equal to $\bar{G}_{1 c}=\left(1+p_{c}\right) G_{1 c}, \bar{G}_{2 c}=G_{2 c}+p_{c} G_{1 c}$ and $\bar{G}_{3 c}=\left(1+p_{c}\right) G_{3 c}-p_{c}\left(G_{2 c}-G_{1 c}\right)$.

Figure 2 focuses on households with one and two children to illustrate FA and two different EITC schedules against gross earnings of the secondary earner, with gross earnings of the primary earner fixed to 15,000 Euros. The two EITC schedules differ only in the size of the benefit premium for two-earner households, which is fixed to $p_{c}=0$ in the standard schedule and $p_{c}=1$ in the new schedule. In both schedules, the income cut-off points $G_{1 c}, G_{2 c}$, and $G_{3 c}$ are fixed to $50 \%, 100 \%$ and $150 \%$ of the poverty line in the baseline tax-benefit system and vary across household groups according to coefficients of the Carbonaro equivalence scale. As noticed above, the benefits from the two EITC schedules expire at lower income cut-off points with respect to FA, and the new EITC schedule has a larger phase-out region than the standard EITC schedule. One-earner households receive higher benefits under the standard EITC schedule. However, as the second-earner enters the labor market, the new EITC schedule provides considerably higher benefits over a wider range of the gross earnings distribution.

\subsection{The WTC reform}

In the WTC reform, eligibility is restricted to households with at least one adult person working 16 hours per week or more. The maximum benefit entitlement is made up by three components: the basic element $W_{1 c}^{*}$, the second adult element $W_{2 c}^{*}$ and the 30 hour 

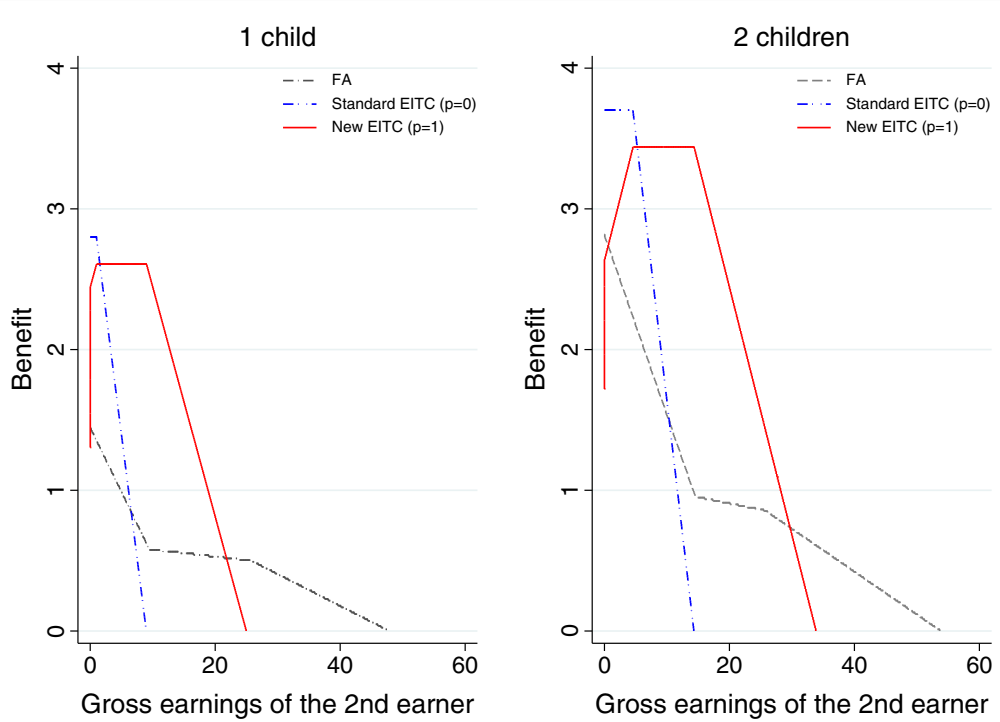

Figure 2 EITC and FA against gross earnings of the secondary earner for households with one and two children. Notes: Benefit amounts and gross earnings of the secondary earner are in 1000 Euros. Gross earnings of the primary earner is fixed to 15,000 Euros. The benefit premium for two-earner households is $p_{C}=0$ in the standard EITC schedule and $p_{C}=1$ in the new EITC schedule.

element $W_{3 c}^{*}$. We assume that $W_{1 c}^{*}$ is provided to all eligible households, $W_{2 c}^{*}$ is provided to households where both spouses work at least 16 hours per week, and $W_{3 c}^{*}$ is provided to households where both spouses work at least 30 hours per week. As before, the basic element $W_{1 c}^{*}$ is determined to achieve budget neutrality within each household group. The other two elements are instead fixed to $W_{2 c}^{*}=p_{c} W_{1 c}^{*}$ and $W_{3 c}^{*}=q_{c} W_{1 c}^{*}$, where $p_{c} \geq 0$ is the benefit premium for two-earner households, and $q_{c} \geq 0$ is the benefit premium for working full-time. The schedule for one-earner households has the standard form

$$
W_{c}=W_{c}^{*}-\max \left\{0, \min \left\{W_{c}^{*}, t_{c}\left(G-G_{2 c}\right)\right\}\right\}, \quad c=1,2,3,4,
$$

where $W_{c}^{*}=W_{1 c}^{*}$ is the maximum benefit of the flat region, $t_{c}=W_{c}^{*} /\left(G_{3 c}-G_{2 c}\right)$ is the taper rate of the phase-out region, and $G_{2 c}$ and $G_{3 c}$ are the income cut-off points delimiting the phase-out region. Here, the first income cut-off point of the flat region is defined implicitly by the eligibility condition placed on hours of work, and it varies across households according to hourly wages of both spouses and non-labor household income. Two-earner households who are entitled to the second adult element face a similar schedule with maximum benefit $\bar{W}_{c}^{*}=W_{1 c}^{*}+W_{2 c}^{*}$, income cut-off points $\bar{G}_{2 c}=G_{2 c}$ and $\bar{G}_{3 c}=G_{3 c}+p_{c}\left(G_{3 c}-G_{2 c}\right)$. If both spouses work full-time, then the maximum benefit is shifted upward to $\tilde{W}_{c}^{*}=W_{1 c}^{*}+W_{2 c}^{*}+W_{3 c}^{*}$, and the income cut-off points are increased to $\tilde{G}_{2 c}=G_{2 c}$ and $\tilde{G}_{3 c}=G_{3 c}+\left(p_{c}+q_{c}\right)\left(G_{3 c}-G_{2 c}\right)$. Thus, two-earner households are entitled to a higher maximum benefit and face a larger phase-out region.

Figure 3 illustrates FA and two different WTC schedules against gross earnings of the secondary earner for households with one and two children. For comparability with the EITC schedules illustrated in Figure 2, common policy coefficients are set as before, and the benefit premium for full-time work is fixed at $q_{c}=0.5$ for all household groups. 

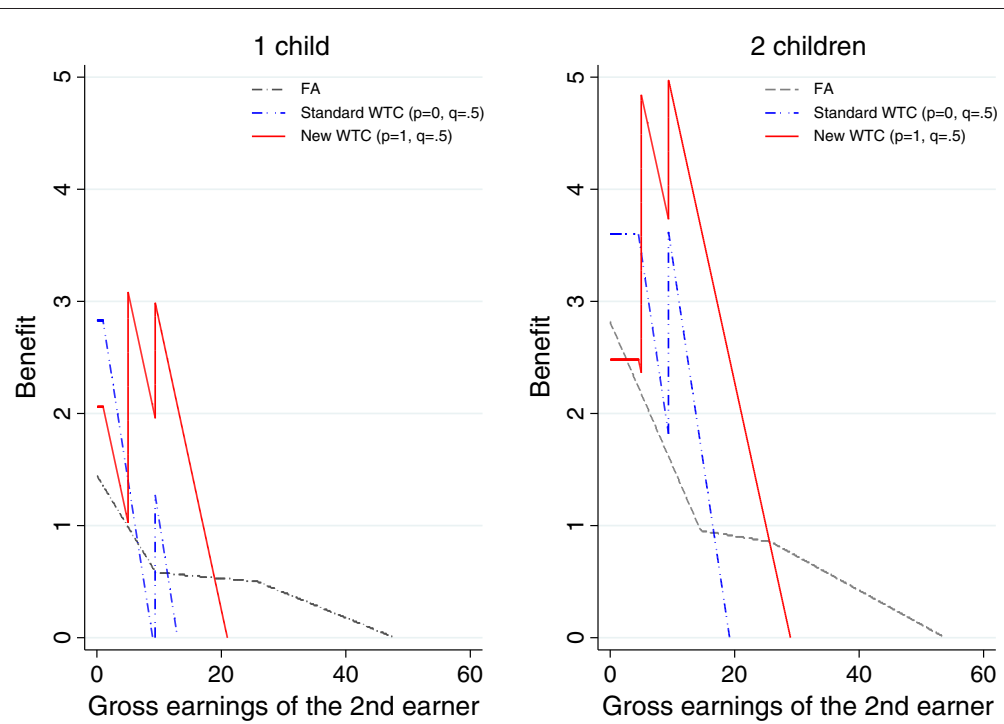

Figure 3 WTC and FA against gross earnings of the secondary earner for households with one and two children. Notes: Benefit amounts and gross earnings of the secondary earner are in 1000 Euros. Gross earnings of the primary earner is fixed to 15,000 Euros for a full-time job, and gross hourly wage of secondary earner is fixed to 6 Euros. The benefit premium for two-earner households is $p_{c}=0$ in the standard WTC schedule and $p_{c}=1$ in the new WTC schedule. The benefit premium for working full-time is $q_{c}=.50$.

Compared to the EITC, this system of in-work benefits is particularly targeted to households with low hourly wages. Further, it provides additional incentives to encourage full-time work.

\section{Evaluation methodology}

The methodology used to provide an ex-ante evaluation of the hypothetical in-work benefit reforms consists of combining a national tax-benefit calculator with a behavioral model of labor supply using data from the Survey on Household Income and Wealth (SHIW). In what follows, we describe the key ingredients of this evaluation tool.

\subsection{Tax-benefit calculator and survey data}

The tax-benefit calculator used in this study is EconLav, an Italian microsimulation model that covers social security contributions, taxes and public transfers. EconLav is applied to a subsample of married couples from the 2008 wave of the SHIW to approximate the budget sets of each sample unit under both the baseline tax-benefit schedule in the year of data collection and the hypothetical schedules resulting from our in-work benefit reforms. Our working sample consists of 1,926 married couples in which the husband and the wife are both aged between 20 and 65 years, and neither of them is disabled, retired, in education, nor engaged in self-employment activities. We also trimmed $1 \%$ of outliers from the observed hourly wage distribution of each spouse. Descriptive statistics on the key variables are presented in the Additional file 1.

\subsection{Behavioral model of labor supply}

For the behavioral model of labor supply, we extend to married couples the multi-sectoral discrete choice model for single decision makers developed by Dagsvik and Strøm (2006). 
Like other models based on a discrete choice approach, labor supply is treated as the outcome of agents' choices from a finite set of job opportunities. Thus, utility maximization is performed by finding the best alternative in this finite set, and it becomes simple handling nonlinear and nonconvex budget sets while also accounting for other important issues faced in the estimation of labor supply models (e.g. flexible specifications of preferences, observed and unobserved heterogeneity, unobserved wages, and quantity constraints on the choice set).

The multi-sectoral framework of Dagsvik and Strøm (2006) extends the standard setup for this class of models by accommodating the separation of jobs in different sectors. Within this framework, each job is characterized by fixed hours of work, a sector-specific hourly wage, and other nonpecuniary and unobservable job attributes. Thus, the hourly wage of each agent can vary across jobs of different sectors, and the set of available jobs is allowed to be individual-specific to capture quantity constraints that are determined by market equilibrium conditions and negotiations between unions and employers within each sector.

Our generalization of this framework to married couples is presented in Appendix A. A key assumption of this model is that it relies on a unitary approach where husband and wife maximize a common household utility function. As argued by Chiappori and Donni (2009); Vermeulen (2002); and Bargain et al. (2010), the income pooling assumption made in this approach is not exempt from criticisms, and it has been rejected in some empirical studies. A more attractive approach would be a collective model where the two spouses are involved in an intra-household bargaining process to maximize their own preferences (see, for example, Vermeulen 2006 and Francesconi et al. 2009). Earlier studies by Beninger et al. (2006); Beninger et al. (2007); Beninger and Laisney (2002); and Chiuri and Longobardi (2002), among others, suggest that imposing a unitary framework when the data-generating process is a collective framework may lead to downward biased estimates of labor supply responses for wives and upward biased estimates of labor supply responses for husbands. In this paper, we shall not follow this more general approach because full estimation of a collective and multi-sectoral labor supply model with taxes like ours has not been achieved yet.

In the empirical analysis, we focus on a two-sector model that distinguishes between jobs in the public and private sectors to capture the non-negligible differences existing in the labor market conditions and the hourly wage structures of these two sectors in the Italian economy (see, for example, Giordano et al. 2011). The predetermined choice set of each agent includes non-participation plus 6 job opportunities for each sector, yielding 169 job combinations for each couple. In modeling quantity constraints on the choice set, we assume that the number of sector-specific jobs available for each spouse depends on education and regional unemployment rates. Further, we assume that their hours of work distributions are uniform apart from two peaks at full-time jobs with 35 and 40 weekly hours of work, respectively, and one peak at part-time jobs with $20-30$ weekly hours of work.

The hourly wage of each agent is allowed to vary among jobs in the public and private sectors but not across jobs within the same sector. This amounts to assuming that hourly wages are independent from hours of work. Since sector-specific hourly wages of the two spouses can never be observed jointly, we estimate a system of four hourly wage equations in an early stage. As described in Appendix B, this estimation stage is based on a 
three-step control function procedure that simultaneously accounts for sector-specific selection effects, endogeneity of experience, and correlations among hourly wages of the husband and the wife.

In addition to the bias correction terms that control for selection in each equation of the system and the reduced form residuals that control for endogeneity of experience, the covariates in the hourly wage equations include a third-order polynomial in experience, two indicators for education attainment, gender-specific regional unemployment rates, and two indicators for living in the center and the south of Italy. Identification of the hourly wage equations is attained through a set of exclusion restrictions: second-order polynomials in age and non-labor income, number of children, and indicators for children aged less than 3 years and occupational status of the parents. In other words, we assume that this set of variables help explain the reduced form equation for experience and the selection equations for the choice of the sector, but not the sector-specific hourly wages of the two spouses. Hourly wage predictions also incorporate prediction errors drawn from a multivariate normal distribution with zero means and a variance-covariance matrix equal to the estimates resulting from our three-step procedure.

The utility function includes a systematic component, which takes the form of a quadratic polynomial expansion in disposable household income, leisure of the husband and leisure of the wife, and a random taste-shifter which is identically and independently distributed across households, sectors and jobs according to an extreme value distribution.

Preference variation across couples is taken into account by modeling the marginal utility of each spouse's leisure in terms of a second-order polynomial in age, number of children, an indicator for children aged less than 3 years, and a random error for unobserved heterogeneity in preferences. The random errors for unobserved heterogeneity in the preferences of husbands and wives are assumed to be mutually independent, independent of prediction errors in the hourly wages, and normally distributed with mean zero and constant variance.

Due to the distributional assumption on the random taste-shifter, the reduced form of the model is equivalent to a multinomial mixed logit model with 169 alternatives and six random errors, two of which account for unobserved heterogeneity in preferences of the two spouses, and four account for prediction errors in their sector-specific hourly wages. Model parameters are estimated via simulated maximum likelihood (SML) to integrate out of the likelihood these unobservable random errors. Provided that the number of draws used in SML goes to infinity faster than the square root of the number of observations, the resulting estimator is known to asymptotically equivalent to the exact maximum likelihood estimator (Hajivassiliou and Ruud 1994).

\subsection{Labor supply predictions}

The SML estimates of our model can be used to predict potential adjustments in labor supply due to changes in the tax-benefit system. In our analysis, these predictions are computed through the procedure of Creedy and Duncan (2002). For each couple, we first draw up to 750 realizations from the extreme value distribution and the estimated asymptotic distribution of the parameter estimates, such that under the baseline tax-benefit system, the observed alternative in the choice set has the highest utility. This gives us one set of draws of the random taste-shifter and the parameters estimates which rationalizes 
the observed labor supply choices of the two spouses under the baseline tax-benefit system. Only for couples where none of the 750 realizations yields maximum utility at the observed alternative, labor supply of the two spouses is considered to be invariant. Through repeated applications of this process, we construct 250 sets of draws for all random components of the model, and for each of them we predict labor supply choices of the two spouses under a reform scenario to obtain 250 predictions of labor supply transitions. Finally, we average over the sample and report the mean and the fifth and ninety-fifth percentiles of the distribution of transitions. These percentiles are the bounds of a two sided confidence interval of about 90 percent.

\section{Estimates of the labor supply model and elasticities}

Table 1 compares the SML estimates of our two-sector model (labeled as Model 2) with those of a benchmark model (labeled as Model 1) which ignores sector-specific attributes of the jobs offered to the two spouses. The SML estimates of both models are based on 50 draws from the distribution of their unobservable random errors.

The estimated coefficients of the terms of the utility function are reported in the upper panel of the table. These estimates suggest that differences between Models 1 and 2 in the coefficients of disposable household income and leisure terms are non negligible. Nevertheless, both models satisfy the first and the second order conditions in van Soest (1995), implying that the deterministic parts of the corresponding utility functions are increasing in their arguments and quasi-concave for all sample observations. Here, a positive coefficient of the interactions between leisure terms and socio-demographic characteristics can be interpreted as a positive effect on the marginal utility of leisure or, equivalently, as a negative effect on labor supply. Accordingly, we find that labor supply has an inverted U-shaped age profile with a maximum at 38 years for husbands and 33 years for wives. The number of children has a negative impact on wives' labor supply, while the presence of young children has negligible effects. Similarly to Haan (2006), we also find that random effects for unobservable heterogeneity in the preferences do not play an important role.

Estimated peaks of the hours of work densities suggest that working opportunities are mainly concentrated around full-time jobs with 40 hours of work. The availability of parttime jobs and full-time jobs with 35 hours of work is particularly low for husbands in the private sector, and one can also notice that estimated peaks from Model 1 are always in the range of their sector-specific estimates from Model 2. Estimated coefficients of the job availability measures imply that couples living in regions with high unemployment rates face a less favorable labor market environment. Moreover, except for husbands in the private sector, the number of jobs offered to the two spouses is positively related to education. Overall, both models fit the observed data very well, and their estimated coefficients are found to be robust to alternative specifications of the predetermined choice-sets for the two spouses.

To investigate the sensitivity of labor supply responses to financial incentives, we present in Table 2 the own and cross wage elasticities of the participation probability (PP) and the unconditional hours of work (HW). These elasticities are computed numerically by simulation using a procedure similar to that discussed in Section 4.3. Specifically, for each household, we first obtain 250 labor supply transitions in response to a $10 \%$ exogenous increase in all gross hourly wages of husbands or wives, leaving the tax-benefit 
Table 1 SML estimates of labor supply models for married couples

\begin{tabular}{|c|c|c|c|c|}
\hline Model component & \multicolumn{2}{|l|}{ Variable } & Model 1 & Model 2 \\
\hline \multirow[t]{19}{*}{ Preferences } & \multicolumn{2}{|l|}{$(\mathrm{DHI} / 1000)$} & $0.9413^{* *}$ & $0.3513^{* *}$ \\
\hline & \multicolumn{2}{|l|}{$(\mathrm{DH} / / 1000)^{2}$} & $-0.0045^{* *}$ & $-0.0012^{* *}$ \\
\hline & \multicolumn{2}{|l|}{ 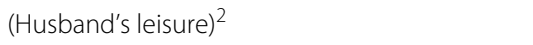 } & $-0.0019^{* *}$ & $-0.0016^{* *}$ \\
\hline & \multicolumn{2}{|l|}{$(\text { Wife's leisure })^{2}$} & $-0.0025^{* *}$ & $-0.0026^{* *}$ \\
\hline & \multicolumn{2}{|c|}{$(\mathrm{DHI} / 1000) \times($ Husband's leisure $)$} & -0.0009 & 0.0007 \\
\hline & \multicolumn{2}{|c|}{ (DHI/1000) × (Wife's leisure $)$} & $-0.0028^{* *}$ & -0.0008 \\
\hline & \multicolumn{2}{|c|}{ (Husband's leisure) × (Wife's leisure) } & 0.0007 & $0.0009^{* *}$ \\
\hline & \multicolumn{2}{|l|}{ (Husband's leisure) } & $0.5268^{* *}$ & $0.4080^{* *}$ \\
\hline & \multicolumn{2}{|l|}{$\times($ Age/10) } & -0.0560 & $-0.0555^{*}$ \\
\hline & \multicolumn{2}{|l|}{$\times(\mathrm{Age} / 10)^{2}$} & $0.0075^{*}$ & $0.0073^{* *}$ \\
\hline & \multicolumn{2}{|c|}{$\times$ No. children } & 0.0030 & 0.0029 \\
\hline & \multicolumn{2}{|c|}{ × Children aged (0-3) } & -0.0111 & -0.0124 \\
\hline & \multicolumn{2}{|c|}{ Standard deviation $\zeta_{m}$} & 0.0027 & 0.0020 \\
\hline & \multicolumn{2}{|l|}{ (Wife's leisure) } & $0.7348^{* *}$ & $0.6520^{* *}$ \\
\hline & \multicolumn{2}{|l|}{$\times($ Age $/ 10)$} & -0.0504 & -0.0391 \\
\hline & \multicolumn{2}{|l|}{$\times(\mathrm{Age} / 10)^{2}$} & $0.0078^{*}$ & $0.0060^{*}$ \\
\hline & \multicolumn{2}{|c|}{$\times$ No. children } & $0.0105^{* *}$ & $0.0079^{* *}$ \\
\hline & \multicolumn{2}{|c|}{$\times$ Children aged (0-3) } & 0.0094 & 0.0092 \\
\hline & \multicolumn{2}{|c|}{ Standard deviation $\zeta_{f}$} & 0.0048 & 0.0004 \\
\hline \multirow[t]{18}{*}{ Hours of work densities } & Husband & Part-time peak & $-3.1684^{* *}$ & \\
\hline & & Full-time peak-35h & $-1.1088^{* *}$ & \\
\hline & & Full-time peak-40h & $0.4886^{* *}$ & \\
\hline & Wife & Part-time peak & -1.2054 & \\
\hline & & Full-time peak-35h & -0.1112 & \\
\hline & & Full-time peak-40h & $1.1022^{*}$ & \\
\hline & Husband - public & Part-time peak & & $-2.2099 * *$ \\
\hline & & Full-time peak-35h & & 0.4483 \\
\hline & & Full-time peak-40h & & $0.7350^{* *}$ \\
\hline & Husband - private & Part-time peak & & $-3.4112^{* *}$ \\
\hline & & Full-time peak-35h & & $-1.8509^{* *}$ \\
\hline & & Full-time peak-40h & & $0.4425^{* *}$ \\
\hline & Wife - public & Part-time peak & & -0.3702 \\
\hline & & Full-time peak-35h & & 1.0504 \\
\hline & & Full-time peak-40h & & $1.3263^{*}$ \\
\hline & Wife - private & Part-time peak & & $-1.6869^{*}$ \\
\hline & & Full-time peak-35h & & -0.9976 \\
\hline & & Full-time peak-40h & & 0.9908 * \\
\hline Job availability measures & Husband & Constant & $2.7391^{* *}$ & \\
\hline & & Secondary educ. & $0.8766^{* *}$ & \\
\hline & & Tertiary educ. & 1.2449 & \\
\hline & & Reg. unemployment & $-0.1241^{* *}$ & \\
\hline & Wife & Constant & $2.1139^{* *}$ & \\
\hline & & Secondary educ. & $0.9326^{* *}$ & \\
\hline & & Tertiary educ. & $1.8226^{* *}$ & \\
\hline & & Reg. unemployment & $-0.2159^{* *}$ & \\
\hline & Husband - public & Constant & & $-2.4705^{*}$ \\
\hline & & Secondary educ. & & $1.8531^{* *}$ \\
\hline & & Tertiary educ. & & $3.2211^{* *}$ \\
\hline & & Reg. unemployment & & 0.0497 \\
\hline
\end{tabular}


Table 1 SML estimates of labor supply models for married couples (Continued)

\begin{tabular}{clc}
\hline Husband - private & Constant & $3.1858^{* *}$ \\
& Secondary educ. & 0.2602 \\
& Tertiary educ. & -0.7316 \\
& Reg. unemployment & $-0.1553^{* *}$ \\
& Constant & $-1.8995^{* *}$ \\
& Secondary educ. & $1.6213^{* *}$ \\
& Tertiary educ. & $3.2079^{* *}$ \\
& Reg. unemployment & $-0.1088^{* *}$ \\
& Constant & $2.1173^{* *}$ \\
& Secondary educ. & $0.4084^{*}$ \\
& Tertiary educ. & -0.1426 \\
& Reg. unemployment & $-0.1625^{* *}$ \\
\hline
\end{tabular}

Notes: Model 1 ignores sector-specific attributes of the various jobs, while Model 2 distinguishes between jobs in the public and the private sectors. SML estimates are based on 50 draws from the distribution of the random effects in each model. DHI denotes disposable household income. $\zeta_{m}$, and $\zeta_{f}$ are random effects for heterogeneity in preferences of husbands and wives, respectively. Asterisks denote *a p-value between $5 \%$ and $1 \%$ and ${ }^{* *}$ a p-value below $1 \%$.

system unchanged. These transitions are constructed using the same sets of draws of the random taste-shifter, and the parameter estimates for which the observed alternative of each couple has maximum utility before increasing the gross hourly wages. We then aggregate over the sample to obtain the relative change in the means of PP and HW and multiply the resulting figures by 10 to obtain the so-called aggregate wage elasticities. Finally, we compute the mean and the 90 percent confidence interval (CI) from the distribution of aggregated wage elasticities. Notice that these elasticities depend on the distribution of the initial gross hourly wages, individuals characteristics, and the baseline tax-benefit system. Own-wage elasticities refer to increases of the own gross hourly wages, while cross-wage elasticities refer to increases of the spouses' gross hourly wages.

Coherently with earlier studies, we find that the own-wage elasticities from both models are considerably higher for wives than for husbands, are decreasing across deciles of the disposable household income distribution, and are mainly driven by changes at the extensive margin of labor supply. Specifically, the own-wage elasticities of PP are equal to 0.13 (CI from 0.09 to 0.18 ) for husbands and 0.58 ( $\mathrm{CI}$ from 0.47 to 0.69 ) for wives, whereas the own-wage elasticities of HW are equal to 0.18 (CI from 0.13 to 0.23 ) and 0.70 (CI from 0.58 to 0.83 ), respectively. The cross-wage elasticities are negative and much smaller in absolute value than own-wage elasticities, and differences in the wage elasticities from Models 1 and 2 are generally negligible.

\section{Simulation of EITC and WTC reforms}

As discussed in Section 3, our policy reforms involve substituting the Italian FA program with an in-work benefit program based on either the EITC or the WTC. The simulations are organized as follows. First, we consider an intermediate policy reform that abolishes the FA program without introducing other income support mechanisms to disentangle how much of the overall policy effects comes from abolishing the existing FA program and how much comes from introducing the new in-work benefit programs. Second, we investigate effectiveness of the proposed policy reforms by focusing on a simulation design where the benefit premium for two-earner households is fixed to $p_{c}=1$. Other things 
Table 2 Labor supply elasticities of husbands and wives with respect to gross hourly wages by decile of disposable household income

\begin{tabular}{|c|c|c|c|c|c|c|c|c|c|c|}
\hline \multirow[b]{2}{*}{ Model } & \multirow[b]{2}{*}{ Outcome } & \multirow[b]{2}{*}{ Spouse } & \multirow[b]{2}{*}{ Decile } & \multirow[b]{2}{*}{ Baseline } & \multicolumn{3}{|c|}{ Own elasticity } & \multicolumn{3}{|c|}{ Cross elasticity } \\
\hline & & & & & Mean & $Q_{5}$ & $Q_{95}$ & Mean & $Q_{5}$ & $Q_{95}$ \\
\hline \multirow[t]{16}{*}{1} & PP & Husband & $|-|||$ & 84.26 & 0.45 & 0.33 & 0.60 & 0.01 & -0.06 & 0.08 \\
\hline & & & $\mid V-V I I$ & 96.76 & 0.06 & 0.01 & 0.11 & -0.03 & -0.07 & 0.01 \\
\hline & & & VIII-X & 98.44 & 0.01 & 0.00 & 0.04 & -0.04 & -0.09 & 0.00 \\
\hline & & & Total & 93.51 & 0.15 & 0.11 & 0.19 & -0.02 & -0.05 & 0.01 \\
\hline & & Wife & $|-|||$ & 12.28 & 3.95 & 2.68 & 5.21 & 0.14 & -0.56 & 0.99 \\
\hline & & & IV-VII & 60.31 & 0.49 & 0.34 & 0.65 & -0.08 & -0.22 & 0.04 \\
\hline & & & VIII-X & 84.58 & 0.14 & 0.06 & 0.20 & -0.14 & -0.25 & -0.04 \\
\hline & & & Total & 53.17 & 0.56 & 0.43 & 0.68 & -0.09 & -0.22 & 0.02 \\
\hline & $\mathrm{HW}$ & Husband & $|-|||$ & 32.40 & 0.52 & 0.38 & 0.69 & 0.03 & -0.07 & 0.12 \\
\hline & & & IV-VII & 38.36 & 0.09 & 0.04 & 0.14 & -0.04 & -0.08 & 0.01 \\
\hline & & & VIII-X & 39.58 & 0.01 & -0.03 & 0.05 & -0.06 & -0.14 & -0.02 \\
\hline & & & Total & 36.94 & 0.18 & 0.13 & 0.23 & -0.03 & -0.07 & 0.00 \\
\hline & & Wife & $|-|||$ & 3.50 & 4.83 & 3.36 & 6.25 & 0.18 & -0.59 & 1.11 \\
\hline & & & IV-VII & 19.48 & 0.59 & 0.42 & 0.77 & -0.11 & -0.24 & 0.03 \\
\hline & & & VIII-X & 28.47 & 0.17 & 0.07 & 0.26 & -0.17 & -0.31 & -0.06 \\
\hline & & & Total & 17.38 & 0.64 & 0.50 & 0.77 & -0.12 & -0.26 & -0.00 \\
\hline \multirow[t]{16}{*}{2} & PP & Husband & $|-|||$ & 84.26 & 0.38 & 0.25 & 0.51 & 0.01 & -0.06 & 0.08 \\
\hline & & & IV-VII & 96.76 & 0.06 & 0.03 & 0.11 & -0.03 & -0.08 & 0.00 \\
\hline & & & VIII-X & 98.44 & 0.02 & 0.00 & 0.04 & -0.04 & -0.09 & 0.00 \\
\hline & & & Total & 93.51 & 0.13 & 0.09 & 0.18 & -0.02 & -0.05 & 0.01 \\
\hline & & Wife & $|-|||$ & 12.28 & 3.94 & 2.82 & 5.07 & 0.53 & -0.14 & 1.27 \\
\hline & & & IV-VII & 60.31 & 0.51 & 0.34 & 0.69 & -0.02 & -0.13 & 0.09 \\
\hline & & & VIII-X & 84.58 & 0.16 & 0.08 & 0.25 & -0.05 & -0.14 & 0.02 \\
\hline & & & Total & 53.17 & 0.58 & 0.47 & 0.69 & 0.00 & -0.10 & 0.10 \\
\hline & HW & Husband & $|-|||$ & 32.40 & 0.46 & 0.33 & 0.61 & 0.03 & -0.05 & 0.12 \\
\hline & & & IV-VII & 38.36 & 0.10 & 0.04 & 0.15 & -0.04 & -0.09 & 0.01 \\
\hline & & & VIIIIX & 39.58 & 0.04 & 0.01 & 0.09 & -0.06 & -0.12 & -0.01 \\
\hline & & & Total & 36.94 & 0.18 & 0.13 & 0.23 & -0.03 & -0.06 & 0.01 \\
\hline & & Wife & $|-|||$ & 3.50 & 4.88 & 3.48 & 6.47 & 0.65 & -0.20 & 1.46 \\
\hline & & & IV-VII & 19.48 & 0.63 & 0.46 & 0.84 & -0.03 & -0.15 & 0.08 \\
\hline & & & VIII-X & 28.47 & 0.24 & 0.14 & 0.35 & -0.07 & -0.17 & 0.01 \\
\hline & & & Total & 17.38 & 0.70 & 0.58 & 0.83 & -0.01 & -0.11 & 0.10 \\
\hline
\end{tabular}

Notes: Elasticities are computed, increasing the gross hourly wages of all jobs by $10 \%$. PP and HW denote the participation probability (in percentage points) and the unconditional hours of work per week, respectively. $Q_{5}$ and $Q_{95}$ denote the fifth and ninety-fifth percentiles, respectively, so that $\left(Q_{5}, Q_{95}\right)$ is a two sided confidence interval of 90 percent.

being equal, this design implies that two-earner households are entitled to a double maximum benefit with respect to one-earner households. Finally, we explore the importance of this policy coefficient by considering four alternative EITC and WTC schedules, with $p_{c}$ ranging from 0 to 1.5 with step 0.5 . In all simulations, the size of the corresponding EITC and WTC programs is always determined to ensure budget neutrality for each household group.

As predicted by the economic theory, the results of our intermediate policy reform confirm that a family-based welfare scheme like the Italian FA program unambiguously reduces labor supply of secondary earners (these results are not presented for the sake of 
brevity). If this program is abolished, then the PP of wives increases by 1.05 percentage points (from $53.17 \%$ to $54.22 \%$ ) and their HW by 0.4 hours per week (from 17.38 to 17.78 ). The effects on labor supply of primary earners are instead ambiguous. The PP of husbands decreases by 0.51 percentage points, but the variation in $\mathrm{HW}$ is not statistically different from zero at the $10 \%$ level. Of course, labor supply effects represent only one face of the coin. Although FA unambiguously contribute to the low participation rate of Italian married women, one cannot ignore the sizeable redistributive effects induced by this welfare program. Its abolition would lead to a reduction of mean disposable household income (DHI) by $1.38 \%$ (from $30,087 €$ to $29,670 €$ ) and to an increase in the poverty gap ratio (PGR) by 1 percentage point (from $4.83 \%$ to $5.84 \%$ ). Surprising, the effect on the poverty head count ratio (HCR) is positive only for households with children and not statistically different from zero ${ }^{3}$.

Tables 3 and 4 present the labor supply effects of the EITC and WTC reforms with $p_{c}=1$ by model specification, household type, decile of disposable household income and sector. Labor supply effects for wives are positive and mainly concentrated at the extensive margin, while labor supply effects for husbands are negligible. According to Model 2, the PP of wives increases from $53.17 \%$ to $55.82 \%$ (CI from $55.14 \%$ to $56.44 \%$ ) under the EITC reform and to $55.07 \%$ (CI from $54.52 \%$ to $55.66 \%$ ) under the WTC reform. Notice that, although these effects partly reflect the abolition of FA, the net contribution of our EITC and WTC reforms on the PP of wives remains sizeable. The EITC seems to be more effective than the WTC in boosting employment of wives. However, after accounting for labor supply responses at the intensive margin, the labor supply effects of the two reforms are not statistically different due to the WTC benefit premium for working full-time. The HW of wives vary from 17.38 hours per week to 18.07 hours (CI from 17.88 to 18.25 ) under the EITC reform and to 17.91 hours (CI from 17.73 to 18.09) under the WTC reform.

Heterogeneity of labor supply responses across population groups seems to be substantial. The effects of both reforms are strongly increasing with household size and decreasing with disposable household income. Under the EITC (WTC) reform, the variation in the PP of wives ranges from a minimum of 0.59 percentage points for childless couples to a maximum of 7.92 percentage points for couples with three children. Since our reforms are calibrated to ensure no financial transfer across household groups, and differences in the underlying labor supply elasticities are negligible, this positive gradient is likely to reflect the greater generosity of FA in favor of large households. The negative gradient with respect to disposable household income reflects instead two effects: the decreasing labor supply elasticities across income deciles and the redistributive nature of our reforms that imposes lower income cut-off points with respect to the FA program (see Figures 2 and 3). As a consequence, most labor supply responses are found at the bottom of the disposable household income distribution where the PP of wives increases from $12.28 \%$ to $16.64 \%$ under the EITC reform and to $15.55 \%$ under the WTC reform.

Models 1 and 2 lead to qualitatively similar policy considerations, but differences in the magnitude of their policy effects are non negligible. Specifically, the benchmark model that ignores sector-specific attributes of the various jobs (Model 1) leads to higher labor supply effects than those obtained from our two-sector model (Model 2). The most striking discrepancies are found in the PP of wives, especially those living in large households 
Table 3 Effects of EITC and WTC reforms on participation probabilities of husbands and wives by model specification, household type, decile of disposable household income and sector

\begin{tabular}{|c|c|c|c|c|c|c|c|c|c|}
\hline \multirow[b]{2}{*}{ Model } & \multirow[b]{2}{*}{ Spouse } & \multirow[b]{2}{*}{ Variable } & \multirow[b]{2}{*}{ Baseline } & \multicolumn{3}{|c|}{ EITC } & \multicolumn{3}{|c|}{ WTC } \\
\hline & & & & Mean & $Q_{5}$ & $Q_{95}$ & Mean & $Q_{5}$ & $Q_{95}$ \\
\hline \multirow[t]{16}{*}{1} & Husbands & 0 children & 93.43 & 93.57 & 93.43 & 93.82 & 93.58 & 93.43 & 93.82 \\
\hline & & 1 child & 94.25 & 94.50 & 94.08 & 94.92 & 94.65 & 94.25 & 95.09 \\
\hline & & 2 children & 93.83 & 93.56 & 92.98 & 94.04 & 93.81 & 93.62 & 94.04 \\
\hline & & 3 children & 88.46 & 87.83 & 86.54 & 88.46 & 88.53 & 87.50 & 89.42 \\
\hline & & $|-|||$ & 84.26 & 84.19 & 83.56 & 84.78 & 84.60 & 84.26 & 84.95 \\
\hline & & $\mid \mathrm{V}-\mathrm{VII}$ & 96.76 & 96.89 & 96.63 & 97.28 & 96.96 & 96.76 & 97.28 \\
\hline & & VIIIIX & 98.44 & 98.44 & 98.44 & 98.44 & 98.42 & 98.27 & 98.44 \\
\hline & & Total & 93.51 & 93.54 & 93.30 & 93.77 & 93.69 & 93.56 & 93.87 \\
\hline & Wives & 0 children & 54.27 & 55.22 & 54.66 & 55.85 & 54.77 & 54.40 & 55.32 \\
\hline & & 1 child & 55.67 & 59.20 & 58.04 & 60.41 & 58.36 & 57.19 & 59.56 \\
\hline & & 2 children & 51.70 & 58.62 & 57.02 & 60.43 & 57.91 & 56.17 & 59.57 \\
\hline & & 3 children & 37.50 & 46.82 & 42.31 & 51.92 & 46.89 & 42.31 & 51.92 \\
\hline & & $|-|||$ & 12.28 & 18.23 & 16.44 & 20.07 & 17.36 & 15.74 & 19.03 \\
\hline & & $\mid \mathrm{V}-\mathrm{VII}$ & 60.31 & 64.37 & 63.29 & 65.63 & 63.74 & 62.65 & 64.85 \\
\hline & & VIII-X & 84.58 & 85.37 & 84.92 & 85.96 & 85.08 & 84.58 & 85.62 \\
\hline & & Total & 53.17 & 56.82 & 56.02 & 57.63 & 56.21 & 55.45 & 56.96 \\
\hline \multirow[t]{20}{*}{2} & Husbands & 0 children & 93.43 & 93.49 & 93.30 & 93.69 & 93.50 & 93.30 & 93.69 \\
\hline & & 1 child & 94.25 & 94.40 & 94.08 & 94.75 & 94.47 & 94.25 & 94.75 \\
\hline & & 2 children & 93.83 & 93.54 & 92.98 & 93.83 & 93.76 & 93.40 & 94.04 \\
\hline & & 3 children & 88.46 & 88.19 & 86.54 & 89.42 & 88.44 & 87.50 & 89.42 \\
\hline & & $|-|||$ & 84.26 & 84.15 & 83.56 & 84.60 & 84.40 & 84.08 & 84.78 \\
\hline & & $\mid \mathrm{V}-\mathrm{V} \|$ & 96.76 & 96.80 & 96.50 & 97.15 & 96.86 & 96.63 & 97.15 \\
\hline & & VIIIIX & 98.44 & 98.43 & 98.27 & 98.44 & 98.41 & 98.27 & 98.44 \\
\hline & & Public & 23.52 & 23.38 & 23.00 & 23.78 & 23.21 & 22.85 & 23.52 \\
\hline & & Private & 69.99 & 70.11 & 69.68 & 70.51 & 70.38 & 70.04 & 70.77 \\
\hline & & Total & 93.51 & 93.49 & 93.30 & 93.67 & 93.59 & 93.46 & 93.72 \\
\hline & Wives & 0 children & 54.27 & 54.83 & 54.53 & 55.19 & 54.51 & 54.14 & 54.93 \\
\hline & & 1 child & 55.67 & 58.04 & 57.02 & 59.22 & 57.17 & 56.35 & 58.21 \\
\hline & & 2 children & 51.70 & 56.92 & 55.11 & 58.72 & 55.76 & 54.26 & 57.23 \\
\hline & & 3 children & 37.50 & 45.42 & 41.35 & 50.00 & 44.17 & 40.38 & 49.04 \\
\hline & & $|-|||$ & 12.28 & 16.64 & 15.22 & 18.34 & 15.55 & 14.36 & 16.96 \\
\hline & & $\mid \mathrm{V}-\mathrm{VII}$ & 60.31 & 63.29 & 62.39 & 64.33 & 62.47 & 61.61 & 63.29 \\
\hline & & VIII-X & 84.58 & 85.08 & 84.75 & 85.62 & 84.78 & 84.40 & 85.27 \\
\hline & & Public & 20.87 & 21.49 & 21.03 & 21.91 & 21.16 & 20.82 & 21.55 \\
\hline & & Private & 32.29 & 34.33 & 33.70 & 34.99 & 33.92 & 33.39 & 34.48 \\
\hline & & Total & 53.17 & 55.82 & 55.14 & 56.44 & 55.07 & 54.52 & 55.66 \\
\hline
\end{tabular}

Notes: $\boldsymbol{Q}_{5}$ and $\boldsymbol{Q}_{\mathbf{9 5}}$ denote the fifth and ninety-fifth percentiles, respectively, so that $\left(\boldsymbol{Q}_{5}, \boldsymbol{Q}_{\mathbf{9 5}}\right)$ is a two sided confidence interval of 90 percent.

and at the bottom of the disposable household income distribution. A cross-sectoral analysis of the policy effects from Model 2 also reveals that most labor market transitions take place in the private sector, where there is a greater availability of jobs and lower hourly wages than the public sector. 
Table 4 Effects of EITC and WTC reforms on unconditional weekly hours of work of husbands and wives by model specification, household type, decile of disposable household income and sector

\begin{tabular}{|c|c|c|c|c|c|c|c|c|c|}
\hline \multirow[b]{2}{*}{ Model } & \multirow[b]{2}{*}{ Spouse } & \multirow[b]{2}{*}{ Variable } & \multirow[b]{2}{*}{ Baseline } & \multicolumn{3}{|c|}{ EITC } & \multicolumn{3}{|c|}{ WTC } \\
\hline & & & & Mean & $Q_{5}$ & $Q_{95}$ & Mean & $Q_{5}$ & $Q_{95}$ \\
\hline \multirow[t]{16}{*}{1} & Husbands & 0 children & 36.95 & 36.97 & 36.85 & 37.11 & 36.94 & 36.82 & 37.07 \\
\hline & & 1 child & 37.04 & 37.09 & 36.86 & 37.34 & 37.00 & 36.79 & 37.23 \\
\hline & & 2 children & 37.23 & 37.17 & 36.89 & 37.40 & 37.09 & 36.86 & 37.31 \\
\hline & & 3 children & 34.90 & 34.81 & 33.89 & 35.53 & 34.79 & 34.09 & 35.38 \\
\hline & & $|-|||$ & 32.40 & 32.49 & 32.20 & 32.81 & 32.43 & 32.21 & 32.64 \\
\hline & & IV-VII & 38.36 & 38.37 & 38.18 & 38.54 & 38.28 & 38.13 & 38.44 \\
\hline & & VIII-X & 39.58 & 39.47 & 39.36 & 39.57 & 39.45 & 39.33 & 39.56 \\
\hline & & Total & 36.94 & 36.94 & 36.82 & 37.05 & 36.88 & 36.77 & 36.98 \\
\hline & Wives & 0 children & 18.55 & 18.75 & 18.57 & 18.96 & 18.66 & 18.52 & 18.80 \\
\hline & & 1 child & 17.87 & 18.72 & 18.34 & 19.09 & 18.56 & 18.21 & 18.97 \\
\hline & & 2 children & 16.20 & 18.12 & 17.52 & 18.63 & 18.02 & 17.50 & 18.55 \\
\hline & & 3 children & 11.39 & 13.96 & 12.60 & 15.67 & 14.16 & 12.69 & 16.15 \\
\hline & & $|-|||$ & 3.50 & 5.26 & 4.73 & 5.78 & 5.01 & 4.49 & 5.61 \\
\hline & & IV-VII & 19.48 & 20.54 & 20.20 & 20.89 & 20.43 & 20.08 & 20.84 \\
\hline & & VIII-X & 28.47 & 28.48 & 28.25 & 28.69 & 28.52 & 28.31 & 28.71 \\
\hline & & Total & 17.38 & 18.33 & 18.08 & 18.59 & 18.23 & 17.98 & 18.48 \\
\hline \multirow[t]{20}{*}{2} & Husbands & 0 children & 36.95 & 36.96 & 36.86 & 37.06 & 36.93 & 36.84 & 37.02 \\
\hline & & 1 child & 37.04 & 37.06 & 36.86 & 37.27 & 37.00 & 36.82 & 37.17 \\
\hline & & 2 children & 37.23 & 37.11 & 36.83 & 37.39 & 37.11 & 36.90 & 37.31 \\
\hline & & 3 children & 34.90 & 34.80 & 34.04 & 35.43 & 34.77 & 34.18 & 35.29 \\
\hline & & $|-|||$ & 32.40 & 32.42 & 32.13 & 32.66 & 32.38 & 32.18 & 32.60 \\
\hline & & IV-VII & 38.36 & 38.34 & 38.18 & 38.50 & 38.30 & 38.16 & 38.43 \\
\hline & & VIII-X & 39.58 & 39.51 & 39.40 & 39.59 & 39.50 & 39.38 & 39.60 \\
\hline & & Public & 8.84 & 8.79 & 8.65 & 8.94 & 8.72 & 8.59 & 8.84 \\
\hline & & Private & 28.09 & 28.12 & 27.94 & 28.28 & 28.17 & 28.00 & 28.33 \\
\hline & & Total & 36.94 & 36.91 & 36.80 & 37.01 & 36.88 & 36.79 & 36.97 \\
\hline & Wives & 0 children & 18.55 & 18.68 & 18.55 & 18.82 & 18.60 & 18.48 & 18.72 \\
\hline & & 1 child & 17.87 & 18.46 & 18.12 & 18.82 & 18.26 & 17.98 & 18.56 \\
\hline & & 2 children & 16.20 & 17.61 & 17.11 & 18.14 & 17.38 & 16.90 & 17.86 \\
\hline & & 3 children & 11.39 & 13.48 & 12.26 & 15.05 & 13.31 & 12.16 & 14.76 \\
\hline & & $|-|||$ & 3.50 & 4.77 & 4.34 & 5.25 & 4.46 & 4.09 & 4.86 \\
\hline & & IV-VII & 19.48 & 20.26 & 19.94 & 20.55 & 20.08 & 19.84 & 20.38 \\
\hline & & VIII-X & 28.47 & 28.47 & 28.31 & 28.63 & 28.48 & 28.33 & 28.64 \\
\hline & & Public & 6.73 & 6.87 & 6.74 & 7.00 & 6.80 & 6.69 & 6.90 \\
\hline & & Private & 10.65 & 11.20 & 11.00 & 11.40 & 11.11 & 10.95 & 11.29 \\
\hline & & Total & 17.38 & 18.07 & 17.88 & 18.25 & 17.91 & 17.73 & 18.09 \\
\hline
\end{tabular}

Notes: $Q_{5}$ and $Q_{95}$ denote the fifth and ninety-fifth percentiles, respectively, so that $\left(Q_{5}, Q_{95}\right)$ is a two sided confidence interval of 90 percent.

The redistributive effects of the EITC and WTC reforms are presented in Table 5. For both reforms, we find a positive effect on DHI of about 1\%, a sizeable reduction in the number of poor households (3.14 percentage points under the EITC and 3.86 percentage points under the WTC), and a small improvement in the living standards of those who remain poor. Furthermore, as for labor supply effects, the magnitude of these 
Table 5 Redistributive effects of EITC and WTC reforms by model specification and household type

\begin{tabular}{|c|c|c|c|c|c|c|c|c|c|}
\hline \multirow[b]{2}{*}{ Model } & \multirow[b]{2}{*}{ Outcome } & \multirow[b]{2}{*}{ Household type } & \multirow[b]{2}{*}{ Baseline } & \multicolumn{3}{|c|}{ EITC } & \multicolumn{3}{|c|}{ WTC } \\
\hline & & & & Mean & $Q_{5}$ & $Q_{95}$ & Mean & $Q_{5}$ & $Q_{95}$ \\
\hline \multirow[t]{15}{*}{1} & $\mathrm{DHI}$ & 0 children & 31.83 & 32.29 & 32.20 & 32.40 & 32.27 & 32.19 & 32.35 \\
\hline & & 1 child & 29.56 & 31.33 & 31.15 & 31.50 & 31.39 & 31.22 & 31.56 \\
\hline & & 2 children & 28.85 & 31.72 & 31.43 & 31.98 & 31.84 & 31.58 & 32.08 \\
\hline & & 3 children & 25.92 & 28.87 & 28.17 & 29.65 & 29.24 & 28.60 & 29.93 \\
\hline & & Total & 30.09 & 31.67 & 31.55 & 31.77 & 31.73 & 31.61 & 31.84 \\
\hline & $\mathrm{HCR}$ & 0 children & 6.57 & 3.87 & 3.68 & 4.07 & 3.79 & 3.55 & 4.07 \\
\hline & & 1 child & 15.40 & 9.78 & 9.31 & 10.32 & 8.91 & 8.46 & 9.31 \\
\hline & & 2 children & 27.45 & 19.31 & 18.30 & 20.43 & 18.33 & 17.23 & 19.36 \\
\hline & & 3 children & 52.88 & 41.18 & 37.50 & 44.23 & 40.88 & 36.54 & 44.23 \\
\hline & & Total & 16.87 & 11.47 & 11.11 & 11.84 & 10.91 & 10.54 & 11.27 \\
\hline & PGR & 0 children & 2.19 & 1.76 & 1.69 & 1.89 & 1.71 & 1.61 & 1.77 \\
\hline & & 1 child & 4.29 & 3.91 & 3.67 & 4.21 & 3.61 & 3.42 & 3.78 \\
\hline & & 2 children & 7.19 & 6.50 & 6.15 & 6.97 & 5.96 & 5.73 & 6.21 \\
\hline & & 3 children & 16.47 & 15.59 & 14.37 & 16.99 & 14.10 & 13.28 & 14.91 \\
\hline & & Total & 4.83 & 4.33 & 4.16 & 4.48 & 4.00 & 3.91 & 4.09 \\
\hline \multirow[t]{15}{*}{2} & $\mathrm{DHI}$ & 0 children & 31.83 & 30.91 & 30.85 & 30.98 & 30.90 & 30.84 & 30.97 \\
\hline & & 1 child & 29.56 & 30.21 & 30.04 & 30.36 & 30.27 & 30.14 & 30.39 \\
\hline & & 2 children & 28.85 & 30.58 & 30.33 & 30.83 & 30.67 & 30.45 & 30.89 \\
\hline & & 3 children & 25.92 & 27.58 & 26.98 & 28.24 & 27.82 & 27.33 & 28.43 \\
\hline & & Total & 30.09 & 30.44 & 30.34 & 30.52 & 30.49 & 30.41 & 30.56 \\
\hline & $\mathrm{HCR}$ & 0 children & 6.57 & 4.05 & 3.94 & 4.20 & 4.11 & 3.94 & 4.34 \\
\hline & & 1 child & 15.40 & 11.93 & 11.34 & 12.52 & 10.75 & 10.32 & 11.34 \\
\hline & & 2 children & 27.45 & 23.89 & 22.77 & 25.11 & 22.37 & 21.49 & 23.40 \\
\hline & & 3 children & 52.88 & 48.94 & 44.23 & 51.92 & 48.58 & 44.23 & 51.92 \\
\hline & & Total & 16.87 & 13.73 & 13.29 & 14.12 & 13.01 & 12.67 & 13.34 \\
\hline & PGR & 0 children & 2.19 & 1.89 & 1.84 & 2.01 & 1.84 & 1.75 & 1.90 \\
\hline & & 1 child & 4.29 & 4.31 & 4.05 & 4.60 & 3.95 & 3.76 & 4.13 \\
\hline & & 2 children & 7.19 & 7.07 & 6.67 & 7.55 & 6.44 & 6.23 & 6.73 \\
\hline & & 3 children & 16.47 & 17.24 & 16.08 & 18.49 & 15.86 & 15.13 & 16.59 \\
\hline & & Total & 4.83 & 4.73 & 4.59 & 4.90 & 4.37 & 4.27 & 4.47 \\
\hline
\end{tabular}

Notes: $\mathrm{DHI}$ denotes disposable household income in 1000 Euros, HCR denotes the poverty head count ratio, and PGR denotes the poverty gap ratio. $Q_{5}$ and $Q_{95}$ denote the fifth and ninety-fifth percentiles, respectively, so that $\left(Q_{5}, Q_{95}\right)$ is a two sided confidence interval of 90 percent.

redistributive effects is typically increasing with household size. Overall, these simulation results reveal that the new in-work benefits more than compensate the negative impact on equity due to the abolition of FA, and thus the proposed policy reforms would improve the existing welfare system in terms of both incentive and redistributive effects.

Table 6 presents the PP of wives, the HCR and the PGR resulting from our sensitivity analysis on the benefit premium for two-earner households. For the simulation designs with $p_{c}=0$, which correspond to the standard EITC and WTC programs with no benefit premium for two-earner households, we find a reduction of about 1 percentage point in the PP of wives and a strong improvement of the two poverty indicators. The effects on 
Table 6 Sensitivity analysis on the benefit premium for two-earner households (Model 2 only)

\begin{tabular}{|c|c|c|c|c|c|c|c|c|c|c|}
\hline \multirow[b]{2}{*}{ Policy } & \multirow[b]{2}{*}{$p_{c}$} & \multicolumn{3}{|c|}{ PP - Wives } & \multicolumn{3}{|c|}{ HCR } & \multicolumn{3}{|c|}{ PGR } \\
\hline & & Mean & $Q_{5}$ & $Q_{95}$ & Mean & $Q_{5}$ & $Q_{95}$ & Mean & $Q_{5}$ & $Q_{95}$ \\
\hline Baseline & & 53.17 & & & 16.87 & & & 4.83 & & \\
\hline \multirow[t]{4}{*}{ EITC } & 0 & 52.17 & 51.71 & 52.60 & 12.38 & 12.10 & 12.67 & 4.25 & 4.18 & 4.33 \\
\hline & 0.50 & 54.38 & 53.95 & 54.83 & 13.29 & 12.98 & 13.60 & 4.44 & 4.35 & 4.55 \\
\hline & 1.00 & 55.82 & 55.14 & 56.44 & 13.73 & 13.29 & 14.12 & 4.73 & 4.59 & 4.90 \\
\hline & 1.50 & 56.47 & 55.76 & 57.27 & 13.88 & 13.34 & 14.33 & 4.95 & 4.75 & 5.16 \\
\hline \multirow[t]{4}{*}{ WTC } & 0 & 52.41 & 51.97 & 52.80 & 12.32 & 12.05 & 12.62 & 4.19 & 4.10 & 4.27 \\
\hline & 0.50 & 53.81 & 53.43 & 54.26 & 12.70 & 12.41 & 12.98 & 4.26 & 4.18 & 4.33 \\
\hline & 1.00 & 55.07 & 54.52 & 55.66 & 13.01 & 12.67 & 13.34 & 4.37 & 4.27 & 4.47 \\
\hline & 1.50 & 56.08 & 55.40 & 56.85 & 13.25 & 12.77 & 13.66 & 4.49 & 4.35 & 4.63 \\
\hline
\end{tabular}

Notes: $\boldsymbol{p}_{\boldsymbol{c}}$ is the benefit premium for two-earner households. $Q_{\mathbf{5}}$ and $\boldsymbol{Q}_{\mathbf{9 5}}$ denote the fifth and ninety-fifth percentiles, respectively, so that $\left(Q_{5}, Q_{95}\right)$ is a two sided confidence interval of 90 percent.

employment of wives is positive only for simulation designs with $p_{c}>0$. However, as $p_{c}$ increases, we also see a clear trade-off between efficiency and equity.

\section{Conclusions}

In this paper, we have provided an ex-ante evaluation on labor supply and redistributive effects of EITC and WTC in-work benefits for Italian married couples using a tax-benefit microsimulation model and a structural model of labor supply. The innovative feature of our policy reforms is that we have augmented the standard design of EITC and WTC inwork benefits with a new benefit premium for two-earner households to overcome the potential disincentive effects that these family-based schemes typically generate on secondary earners. Unlike the usual dichotomization between family and individual-based in-work benefits, this policy design provides a smooth mechanism for handing the wellknown trade-off between labor supply and redistributive effects within a single welfare instrument.

Our revenue neutral simulations show that in-work benefits with a suitable scheme of incentives for secondary earners may greatly improve the current Italian tax-benefit system in terms of both incentive and redistributive effects. The EITC is more effective than the WTC in boosting employment, while the WTC is more effective than the EITC in fighting poverty. In both schemes, the trade-off between incentive and redistributive effects depends crucially on the size of new benefit premium for two-earner households. Whether this trade-off can be formalized as a problem of optimal mechanism design is a interesting research topic which is left to future work.

\section{Endnotes}

${ }^{1}$ For additional details on the EITC see http://www.irs.gov/publications/p596.

${ }^{2}$ For additional details on the WTC see http://www.litrg.org.uk/low-income-workers/ tax-credits.

${ }^{3}$ The HCR is defined by the proportion of households with disposable income below the poverty line, while the PGR is defined by the means gap between the poverty line and disposable household income as a proportion of the poverty line by counting the non-poor as having a zero poverty gap. 


\section{Appendix A: A multi-sector model of labor supply for married couples}

We consider a unitary framework in which husband and wife maximize a common household utility function of the form

$$
U=V\left(l_{m}, l_{f}, y\right)+\epsilon(s, k)
$$

where $V\left(l_{m}, l_{f}, y\right)$ is a systematic component, $l_{m}$ is the husband's leisure, $l_{f}$ is the wife's leisure, $y$ is disposable household income, $\epsilon(s, k)$ is a positive random taste-shifter, and $s=\left(s_{m}, s_{f}\right)$ and $k=\left(k_{m}, k_{f}\right)$ index, respectively, the sector combination and the combination of jobs for the husband and the wife. The error $\epsilon(s, k)$ is assumed to be i.i.d. across households, sectors and jobs with c.d.f. $\operatorname{Pr}\{\epsilon<x\}=\exp (-\exp (-1 / x))$, for real $x$. The budget constraint of the couple is $y=\psi\left(h_{m} \omega_{m}\left(s_{m}\right), h_{f} \omega_{f}\left(s_{f}\right) ; I\right)$, where $h_{m}$ and $h_{f}$ are the hours of work of the husband and the wife, $\omega_{m}\left(s_{m}\right)$ and $\omega_{f}\left(s_{f}\right)$ are their sector-specific hourly wages, $I$ is non-labor household income, and $\psi$ is a tax-benefit function. Provided that the utility is increasing in $y$, we obtain

$$
U=v\left(z_{m}, z_{f} ; I\right)+\epsilon(s, k)
$$

where $z_{i}=\left(h_{i}, s_{i}\right), i=m, f$, and $v\left(z_{m}, z_{f} ; I\right)=V\left(l_{m}, l_{f}, \psi\left(h_{m} \omega_{m}\left(s_{m}\right), h_{f} \omega_{f}\left(s_{f}\right) ; I\right)\right)$.

The choice sets of jobs offered to the husband and the wife are assumed to be independent from each other, and each of them consists of a finite number of alternatives. The hours of work of each job are fixed, but there can be several job opportunities with the same working requirements that differ because of other nonpecuniary characteristics.

Since the size of the choice sets is unknown to the researcher, we denote by $Q\left(z_{m}, z_{f}\right)$ the set of job pairs with hours of work $\left(h_{m}, h_{f}\right)$ in sectors $\left(s_{m}, s_{f}\right)$ and by $q_{i}\left(z_{i}\right)$ the number of jobs available to spouse $i=m, f$ with hours of work $h_{i}$ in sector $s_{i}$. It follows that the probability of selecting a specific job pair $k=\left(k_{m}, k_{f}\right)$ with characteristics $\left(z_{m}, z_{f}\right)$ is equal to the sum of the selection probabilities for all jobs in $Q\left(z_{m}, z_{f}\right)$ with the same observable characteristics. Thus, for job pairs with $h_{m}>0$ and $h_{f}>0$, we obtain

$$
\pi\left(z_{m}, z_{f}\right)=\frac{\nu\left(z_{m}, z_{f} ; I\right) q_{m}\left(z_{m}\right) q_{f}\left(z_{f}\right)}{P}
$$

where $P$ is a normalization constant of the form

$$
\begin{aligned}
P= & v(0,0,0,0 ; I)+\sum_{x_{m}>0} \sum_{s_{m}} v\left(x_{m}, s_{m}, 0,0 ; I\right) q_{m}\left(x_{m}, s_{m}\right)+\sum_{x_{f}>0} \sum_{s_{f}} v\left(0,0, x_{f}, s_{f} ; I\right) q_{f}\left(x_{f}, s_{f}\right) \\
& +\sum_{x_{m}>0} \sum_{x_{f}>0} \sum_{s_{m}} \sum_{s_{f}} v\left(x_{m}, s_{m}, x_{f}, s_{f} ; I\right) q_{m}\left(x_{m}, s_{m}\right) q_{f}\left(x_{f}, s_{f}\right) .
\end{aligned}
$$

The choice probabilities of the other job pairs have a similar form.

Following Dagsvik and Strøm S (2006), we can also re-parameterize the number of available jobs to foster interpretation. Let $q_{i}\left(z_{i}\right)=\theta_{i}\left(s_{i}\right) g_{i}\left(z_{i}\right)$ with $\theta_{i}\left(s_{i}\right)=\sum_{x_{i}>0} q_{i}\left(x_{i}, s_{i}\right)$ for alternatives with $h_{i}>0$ and $\theta_{i}\left(s_{i}\right)=g_{i}\left(z_{i}\right)=1$ for alternatives with $h_{i}=0$. It follows that $\theta_{i}\left(s_{i}\right)$ measures the number of job opportunities relative to nonworking opportunities that are available to spouse $i$ in sector $s_{i}$, whereas $g_{i}\left(z_{i}\right)$ measures the share of jobs with $h_{i}$ hours of work that are available to spouse $i$ in sector $s_{i}$. 


\section{Appendix B: Estimation of sector-specific hourly wage equations of husbands and wives}

Let $j_{1}$ and $j_{2}$ be two indicators for the sectors of husband and wife, respectively, with $j_{s}=0$ denoting non-participation, $j_{s}=1$ public sector, and $j_{s}=2$ private sector $(s=1,2)$. Ignoring endogenity problems, our system of hourly wage equations can be written as

$$
\begin{aligned}
& \ln w_{1}=X_{1}^{\top} \beta_{1}+\eta_{1} \quad \text { if } \quad j_{1}=1, \quad \text { (Husband - Public) } \\
& \ln w_{2}=X_{2}^{\top} \beta_{2}+\eta_{2} \quad \text { if } \quad j_{2}=1, \quad \text { (Wife - Public) } \\
& \ln w_{3}=X_{3}^{\top} \beta_{3}+\eta_{3} \quad \text { if } \quad j_{1}=2, \quad \text { (Husband - Private) } \\
& \ln w_{4}=X_{4}^{\top} \beta_{4}+\eta_{4} \quad \text { if } \quad j_{2}=2, \quad \text { (Wife - Private) }
\end{aligned}
$$

where $X_{t}(t=1, \ldots, 4)$ are vectors of exogenous variables, $\beta_{t}$ are the associated vectors of parameters, and $\eta_{t}$ are error terms with $\mathrm{E}\left(\eta_{t} \mid X_{t}\right)=0, \operatorname{Var}\left(\eta_{t} \mid X_{t}\right)=\sigma_{t}^{2}$, and $\operatorname{Cov}\left(\eta_{t}, \eta_{q} \mid X_{t}, X_{q}\right)=\sigma_{t q}(t \neq q)$. As pointed out by Maddala (1983) in the context of switching regression models, the covariances $\sigma_{13}$ and $\sigma_{24}$ are not estimable because sector-specific hourly wages of the same agent can never be observed simultaneously. Hence, there is no loss of generality in setting these two parameters to zero. The remaining covariances can be identified from the subsamples where hourly wages of the husband and the wife are both observed. In general, however, for consistent estimation one needs to model the selection mechanisms of the two spouses jointly. Hence, we assume that utility of a couple in the sector combination $\left(j_{1}, j_{2}\right)$ is

$$
U_{j_{1} j_{2}}^{*}=Z^{\top} \gamma_{j_{1} j_{2}}+\epsilon_{j_{1} j_{2}}
$$

where $Z$ is a vector of exogenous variables, $\gamma_{j_{1 j}}$ are vectors of parameters, and $\epsilon_{j_{1 j} j_{2}}$ are i.i.d. errors independent of $Z$ with a type-I extreme value distribution. Under this distributional assumption, selection probabilities have the standard multinomial logit form

$$
P_{j_{1} j_{2}}=P\left(U_{j_{1} j_{2}}^{*}=\max _{k_{1}, k_{2}} U_{k_{1} k_{2}}^{*}\right)=\frac{\exp \left(Z^{\top} \gamma_{j_{1} j_{2}}\right)}{\sum_{k_{1}, k_{2}} \exp \left(Z^{\top} \gamma_{k_{1} k_{2}}\right)},
$$

with $k_{1}, k_{2}=0,1,2$. To model sample selection, we allow the errors in the outcome equations of interest to be correlated with the errors in the multinomial selection equation on the basis of

$$
\begin{aligned}
& \mathrm{E}\left(\eta_{1} \mid \epsilon_{00}, \ldots, \epsilon_{22}\right)=\sigma_{1} \frac{\sqrt{6}}{\pi} \sum_{k_{2}} r_{1.1 k_{2}} \epsilon_{1 k_{2}}^{*}, \\
& \mathrm{E}\left(\eta_{2} \mid \epsilon_{00}, \ldots, \epsilon_{22}\right)=\sigma_{2} \frac{\sqrt{6}}{\pi} \sum_{k_{1}} r_{2 . k_{1} 1} \epsilon_{k_{1} 1}^{*}, \\
& \mathrm{E}\left(\eta_{3} \mid \epsilon_{00}, \ldots, \epsilon_{22}\right)=\sigma_{3} \frac{\sqrt{6}}{\pi} \sum_{k_{2}} r_{3.2 k_{2}} \epsilon_{2 k_{2}}^{*}, \\
& \mathrm{E}\left(\eta_{4} \mid \epsilon_{00}, \ldots, \epsilon_{22}\right)=\sigma_{4} \frac{\sqrt{6}}{\pi} \sum_{k_{1}} r_{4 . k_{1} 2} \epsilon_{k_{1} 2}^{*},
\end{aligned}
$$

where $\epsilon_{k_{1} k_{2}}^{*}=\epsilon_{k_{1} k_{2}}-\mathrm{E}\left(\epsilon_{k_{1} k_{2}}\right)$ and $r_{t . k_{1} k_{2}}$ denote the correlation coefficient between $\eta_{t}$ and $\epsilon_{k_{1} k_{2}}$. Provided that the model is correctly specified, all identifiable parameters in (2)-(4) can be estimated consistently by the two-step procedure of De Luca (2014), which extends to SURE models the approach of Durbin and McFadden (1984) for consistent 
estimation of a single outcome equation with a multinomial selection rule. Let us consider for simplicity the first equation of (4). The results in De Luca (2014) imply that

$$
\mathrm{E}\left(\eta_{1} \mid j_{1}=1\right)=\sigma_{1} \frac{\sqrt{6}}{\pi} \sum_{k_{2}} r_{1.1 k_{2}} \Lambda_{1.1 k_{2}}
$$

where $\Lambda_{1.1 k_{2}}$ are the bias correction terms of the form,

$$
\Lambda_{1.1 k_{2}}=\left\{\begin{array}{lll}
P_{1 .}^{-1}\left(P_{1 .}-P_{1 k_{2}}\right) \lambda_{1 k_{2}}-P_{1 .}^{-1} P_{1 k_{2}} \ln P_{1 k_{2}} & \text { if } & k_{1}=1 \\
\lambda_{1 k_{2}} & \text { if } & k_{1} \neq 1
\end{array}\right.
$$

with $P_{1 .}=\sum_{k_{2}} P_{1 k_{2}}$ and $\lambda_{1 k_{2}}=\left(1-P_{1 k_{2}}\right)^{-1} P_{1 k_{2}} \ln P_{1 k_{2}}$. Thus, $\beta_{1}$ and the coefficients on the bias correction terms can be estimated consistently by OLS on the basis of

$$
\ln w_{1}=X_{1}^{\top} \beta_{1}+\sigma_{1} \frac{\sqrt{6}}{\pi} \sum_{k_{2}} r_{1.1 k_{2}} \Lambda_{1.1 k_{2}}+u_{1}, \quad \text { if } \quad j_{1}=1
$$

where $\mathrm{E}\left(u_{1} \mid j_{1}=1\right)=0$. A consistent estimate of $\sigma_{1}$ can be also recovered from

$$
\operatorname{Var}\left(u_{1} \mid j_{1}=1\right)=\sigma_{1}^{2}\left(1+\Delta_{1}\right)
$$

where

$$
\Delta_{1}=\frac{6}{\pi^{2}} \sum_{k_{2}} r_{1.1 k_{2}}^{2}\left(\Delta_{1.1 k_{2}}-\frac{\lambda_{1 k_{2}}^{2}}{P_{1 k_{2}}}\right)
$$

with

$$
\Delta_{1.1 k_{2}}=\frac{\lambda_{1 k_{2}}^{2}}{P_{1 .}}+\frac{P_{1 k_{2}}}{P_{1 .}}\left(\ln P_{1 k_{2}}\right)^{2}+\left(1-\frac{P_{1 k_{2}}}{P_{1 .}}\right) \lambda_{1 k_{2}}^{2}-\left(1-\frac{1}{P_{1 .}}\right)^{2} \lambda_{1 k_{2}}^{2} .
$$

Moreover, if $u_{2}$ denotes the error in the augmented regression model for the second equation of the system, then a consistent estimate of $\sigma_{12}$ can be recovered from

$$
\mathrm{E}\left(u_{1} u_{2} \mid j_{1}=1, j_{2}=1\right)=\sigma_{12}+\sigma_{1} \sigma_{2} \frac{6}{\pi^{2}} \Lambda_{1}^{*} \Lambda_{2}^{*}
$$

where $\Lambda_{1}^{*}=\sum_{k_{2}} r_{1.1 k_{2}} \Lambda_{1.1 k_{2}}$ and $\Lambda_{2}^{*}=\sum_{k_{1}} r_{2 . k_{1} 1} \Lambda_{2 . k_{1} 1}$.

Results for the other equations of the system can be obtained in a similar fashion. In addition, this setup can be easily extended to account for endogeneity problems by incorporating in (6) residual terms from reduced form equations for the endogenous variables (see, for example, Das et al. 2003).

Our control function procedure then consists of three steps. In the first step, we estimate reduced form equations for experience of each spouse. In the second step, we estimate the multinomial logit model in (3) and compute consistent estimates of the bias correction terms in (6)-(8). In the third step, we estimate augmented regression models like (6) by OLS, including as additional regressors reduced form residuals from the first step and bias correction terms from the second step. Consistent estimates of the variances $\sigma_{t}^{2}$ are obtained from (7) using the sum of squared residuals over the subsample where each wage equation is observed, while consistent estimates of the identifiable covariances $\sigma_{t q}$ are obtained from (8) using the sum of cross-products of the residuals over the subsamples where two wage equations are both observed. Standard errors of the thirdstep estimates are computed by nonparametric bootstrap. The third-step estimates of our system of hourly wage equations are presented in Table 7. 
Table 7 Log hourly wages estimates of husband and wife

\begin{tabular}{|c|c|c|c|c|c|c|}
\hline \multirow{3}{*}{ Conditional mean } & \multicolumn{2}{|c|}{ Model 1} & \multicolumn{4}{|c|}{ Model 2} \\
\hline & \multirow[b]{2}{*}{ Husband } & \multirow[b]{2}{*}{ Wife } & \multicolumn{2}{|c|}{ Public sector } & \multicolumn{2}{|c|}{ Private sector } \\
\hline & & & Husband & Wife & Husband & Wife \\
\hline Experience & $0.0150^{* *}$ & $0.0308^{* *}$ & $0.0156^{* *}$ & $0.0259^{* *}$ & $0.0123^{* *}$ & $0.0201 * *$ \\
\hline Experience $^{2}$ & $-0.0003^{*}$ & -0.0002 & -0.0002 & $-0.0006^{*}$ & $-0.0004^{*}$ & -0.0002 \\
\hline Experience $^{3}$ & 0.0000 & 0.0000 & 0.0000 & 0.0000 & 0.0000 & 0.0000 \\
\hline Secondary educ. & $0.2658^{* *}$ & $0.2028^{* *}$ & $0.2569^{* *}$ & $0.3157^{* *}$ & $0.2368^{* *}$ & $0.1156^{*}$ \\
\hline Tertiary educ. & $0.7077^{* *}$ & $0.6050^{* *}$ & $0.7807^{* *}$ & $0.6442^{* *}$ & $0.5672^{* *}$ & $0.4309^{* *}$ \\
\hline Reg unemployment & $-0.0188^{* *}$ & 0.0168 & 0.0111 & 0.0166 & $-0.0404^{* *}$ & -0.0138 \\
\hline Center & $0.0614^{*}$ & $0.109^{*}$ & 0.0051 & $0.1306^{*}$ & $0.0932^{* *}$ & $0.1266^{*}$ \\
\hline South & 0.028 & 0.0296 & -0.1475 & 0.0255 & 0.1075 & 0.0564 \\
\hline$\Lambda_{1.11}$ & -0.2700 & & 0.0084 & & & \\
\hline$\Lambda_{1.12}$ & -0.0224 & & -0.0377 & & & \\
\hline$\Lambda_{1.13}$ & & & 0.1166 & & & \\
\hline$\Lambda_{2.21}$ & & -0.3833 & & -0.0857 & & \\
\hline$\Lambda_{2.22}$ & & 0.0099 & & -0.0249 & & \\
\hline$\Lambda_{2.23}$ & & & & 0.0276 & & \\
\hline$\Lambda_{3.31}$ & & & & & 0.0201 & \\
\hline$\Lambda_{3.32}$ & & & & & $0.6129 * *$ & \\
\hline$\Lambda_{3.33}$ & & & & & $-0.5029^{*}$ & \\
\hline$\Lambda_{4.41}$ & & & & & & -0.0658 \\
\hline$\Lambda_{4.42}$ & & & & & & 0.2022 \\
\hline$\Lambda_{4.43}$ & & & & & & -0.0629 \\
\hline$\hat{\omega}$ & $-0.0143^{* *}$ & $-0.0272^{* *}$ & $-0.0205^{* *}$ & $-0.0248^{* *}$ & $-0.0074^{*}$ & -0.0166 \\
\hline$\hat{\omega}^{2}$ & $-0.0011^{*}$ & $-0.0009^{* *}$ & $-0.0022^{* *}$ & -0.0006 & -0.0008 & $-0.0009^{*}$ \\
\hline$\hat{\omega}^{3}$ & $-0.0001^{* *}$ & 0.0000 & -0.0001 & $0.0001^{*}$ & -0.0000 & 0.0000 \\
\hline Constant & $2.3001^{* *}$ & $2.0488^{* *}$ & $2.2215^{* *}$ & $2.0816^{* *}$ & 2.3909 & $2.2094^{* *}$ \\
\hline \multirow[t]{2}{*}{ Variance matrix } & & & \multicolumn{2}{|c|}{ Public sector } & \multicolumn{2}{|c|}{ Private sector } \\
\hline & Husband & Wife & Husband & Wife & Husband & Wife \\
\hline Husband & $0.3926^{* *}$ & $0.0466^{* *}$ & & & & \\
\hline Wife & & $0.4175^{* *}$ & & & & \\
\hline Public Husband & & & $0.3437^{* *}$ & $0.0414^{* *}$ & & -0.0004 \\
\hline Wife & & & & $0.3551^{* *}$ & $0.0284^{* *}$ & \\
\hline Private Husband & & & & & $0.3063^{* *}$ & $0.0527^{* *}$ \\
\hline Wife & & & & & & $0.4318^{* *}$ \\
\hline
\end{tabular}

\section{Additional file}

Additional file 1: Table S1. Mean and standard deviation (SD) of the main variables by gender

Competing interests

The IZA Journal of Labor Policy is committed to the IZA Guiding Principles of Research Integrity. The authors declare that they have observed these principles.

\section{Acknowledgements}

We thank Ugo Colombino, John Dagsvik, Daniela Del Boca, Domenico Depalo, Franco Peracchi and seminar participants at the University of Siena, Italian Ministry of Economics and Finance (Rome), ICEEE Conference 2013 (Genova) and RES Conference 2013 (London) for helpful comments. We also thank the editor Juan F. Jimeno and two anonymous referees for their suggestions. This paper uses EconLav, a tax-benefit microsimulation model developed by ISFOL with the support of the Italian Ministry of Economics and Finance and the Italian Ministry of Labor. The authors are responsible for all errors and interpretations.

Responsible editor: Juan F Jimeno 


\section{Author details}

${ }^{1}$ SEAS Department, University of Palermo, Palermo, Italy. ${ }^{2}$ LUISS Guido Carli, Roma, Italy. ${ }^{3}$ Department of Economics and Finance, University of Rome Tor Vergata, Rome, Italy; CEIS, IZA and CESIfo.

\section{Received: 12 December 2013 Accepted: 26 September 2014}

Published: 10 Nov 2014

\section{References}

Bargain O, Caliendo M, Haan P, Orsini K (2010) 'Making work pay' in a rationed labour market. J Popul Econ 21 (1):323-351 Bargain O, Orsini K (2006) In-work policies in Europe: killing two birds with one stone? Labour Econ 13:667-697

Beninger D, Bargain O, Beblo M, Blundell R, Carrasco R, Chiuri M, Laisney F, Lechene V, Longobardi E, Moreau N, Myck M, Ruiz-Castillo J, Vermeulen F (2006) Tax reform analysis: the choice of the representation of household decision processes does matter. Rev Econ Household 4:159-180

Beninger D, Laisney F (2002) Comparison between unitary and collective models of household labor supply with taxation, zEW Discussion Papers 02-65

Beninger D, Laisney F, Beblo M (2007) Welfare analysis of fiscal reforms: Does the representation of the family decision process matter? Evidence for Germany. J Popul Econ 20(4):869-893

Blundell R (2000) Work incentives and 'in-work' benefit reforms: a review. Oxford Rev Econ Policy 16:27-44

Blundell R, Duncan A, Costas M (2002) Evaluating the working families tax credit, background Paper for 'Structural versus Non-Structural Approaches to Evaluation', Social Policy Monitoring Network, IFS, London, UK. Available at http://www.iadb.org/res/files/blundellwftc-17-11-02.pdf

Blundell R, Duncan A, McCrae J, Costas M (2000) The labor market impact of the working families tax credit. Fiscal Stu 21:75-104

Blundell R, Hoynes H (2004) Has in-work benefit reform helped the labour market? In: Blundell R, Card D, Freeman R (eds). Seeking a Premier League Economy. University of Chicago Press, Chicago. pp 411-460

Blundell R, Shephard A (2012) Employment, hours of work and the optimal taxation of low-income families, Oxford University Press. Rev. Econ. Stud. 72(2):481-510

Brewer M (2000) Comparing in-work benefits and financial work incentives for low-income families in the us and the uk. Working Paper 00/16, The Institute for Fiscal Studies

Brewer M, Duncan A, Shepard A, Suarez M (2006) Did working families tax credit work? The impact of in-work support on labour supply in Great Britain. Labour Econ 13:699-720

Brewer M, Saez E, Shepard A (2010) Means-testing and tax rates on earnings. In: Adam S, Besley T, Blundell R, Bond S, Chote R, Gammie M, Johnson P, Myles G, Poterba J (eds). Dimensions of tax design: The Mirrlees Review. Oxford University Press, New York. pp 90-201

Chiappori P, Donni O (2009) Non-unitary models of household behavior: a survey of the literature. IZA Discussion Papers 4603, Institute for the Study of Labor (IZA), Germany. Available at http://ftp.iza.org/dp4603.pdf

Chiuri M, Longobardi E (2002) Welfare analysis of fiscal reforms in Europe: Does the representation of family decision processes matter? Evidence from Italy, dipartimento di Scienze Economiche e Metodi Matematici - Universita' di Bari, series 0007, Italy. Available at http://www.dse.uniba.it/Quaderni/SERIES/WP_0007.pdf

Colonna F, Marcassa S (2011) Taxation and labor force participation. The case of Italy. Available at http://stefaniamarcassa. webstarts.com/uploads/ColonnaMarcassaTaxLFP_IZA.pdf

Creedy J, Duncan A (2002) Behavioural microsimulation with labour supply responses. J Econ Surv 16:1-39

Dagsvik J, Strøm S (2006) Sectoral labour supply, choice restrictions and functional form. J Appl Econometrics 21:803-826

Das M, Newey W, Vella F (2003) Nonparametric estimation of sample selection models. Rev Econ Stud 70(1):33-58

De Luca G (2014) Consistent estimation of SURE models with sample selection, mimeo. University of Palermo, Italy

Dickert S, Houser S, Scholz J (1995) The earned income tax credit and transfer programs: a study of labor market and program participation. In: Poterba JM (ed). Tax policy and the economy. National Bureau of Economic Research and the MIT Press. MA, Cambridge. pp 1-50

Durbin J, McFadden D (1984) An econometric analysis of residential electric appliance holdings and consumption. Econometrica 52:345-362

Eissa N, Hoynes H (2004) Taxes and the labor market participation of married couples: The earned income tax credit. J Public Econ 88:1931-1958

Eissa N, Liebman J (1996) Labor supply responses to the earned income tax credit. Q J Econ 111:605-637

Figari F (2011) From housewives to independent earners: Can the tax system help Italian women to work? ISER WP 15-2011, UK. Available at https://www.iser.essex.ac.uk/publications/working-papers/iser/2011-15.pdf

Francesconi M, Rainer H, van der Klaauw W (2009) The effects of in-work benefit reform in Britain on couples: Theory and evidence. Econ J 119:66-100

Francesconi M, van der Klaauw W (2007) The socioeconomic consequences of "in-work" benefit reform for British lone mothers. J Hum Resour 42:1-31

Giordano R, Depalo D, Pereira M, Eugéne B, Papapetrou E, Perez J, Reiss L, Roter M (2011) The public sector pay gap in a selection of EURO area countries. Working Paper Series 1406, European Central Bank. Available at http://www.ecb. europa.eu/pub/pdf/scpwps/ecbwp1406.pdf

Gregg P, Harkness S, Smith S (2009) Welfare reform and lone parents in the UK. Econ J 119:38-65

Haan P (2006) Much ado about nothing: Conditional logit vs. random coefficient models for estimating labour supply elasticities. Appl Econ Lett 13:251-256

Hajivassiliou V, Ruud P (1994) Classical estimation methods for LDV models using simulation. In: Engle R, McFadden D (eds). Handbook of Econometrics IV. Elsevier, North-Holland, USA. pp 2384-2443

Immervoll H, Pearson M (2009) A good time for making work pay? Taking stock of in-work benefits and related measures across the OECD. Social, Employment and Migration Working Papers 81, OECD. Available at http://dx.doi.org/10. $1787 / 225442803245$

Leigh A (2007) Earned income tax credits and supply: evidence from a British natural experiment. Natl Tax J 60:205-224 
Liebman J (1998) The impact of the earned income tax credit on incentives and the income distribution. In: Poterba J (ed). Tax Policy and the Economy. Vol. 12. MIT Press, Cambridge

Maddala G (1983) Limited-dependent and qualitative variables in economics. Cambridge University Press, New York Meyer B, Rosenbaum D (2001) Welfare, the earned income tax credit, and the labor supply of single mothers. Q J Econ 116:1063-1114

Neumark D, Wascher W (2001) Using the EITC to help poor families: New evidence and a comparison with the minimum wage. Natl Tax J 54:281-318

van Soest A (1995) Structural models of family labor supply: a discrete choice approach. J Hum Resour 30:63-88

Vermeulen F (2002) Collective household models: principles and main results. J Econ Surv 16:533-564

Vermeulen, F (2006) A collective model for female labour supply with non-participation and taxation. J Popul Econ

19:99-118

10.1186/2193-9004-3-23

Cite this article as: De Luca et al:: In-work benefits for married couples: an ex-ante evaluation of EITC and WTC policies in Italy. IZA Journal of Labor Policy 2014, 3:23

Submit your manuscript to a SpringerOpen ${ }^{\odot}$ journal and benefit from:

- Convenient online submission

- Rigorous peer review

- Immediate publication on acceptance

- Open access: articles freely available online

- High visibility within the field

Retaining the copyright to your article

Submit your next manuscript at $\boldsymbol{\triangleright}$ springeropen.com 